\title{
A Good Persuasion: Becoming Lysander in William Shakespeare's "A Midsummer Night's Dream"
}

Landon Green

Follow this and additional works at: https://researchrepository.wvu.edu/etd

\section{Recommended Citation}

Green, Landon, "A Good Persuasion: Becoming Lysander in William Shakespeare's "A Midsummer Night's Dream"'" (2015). Graduate Theses, Dissertations, and Problem Reports. 5708.

https://researchrepository.wvu.edu/etd/5708

This Thesis is protected by copyright and/or related rights. It has been brought to you by the The Research Repository @ WVU with permission from the rights-holder(s). You are free to use this Thesis in any way that is permitted by the copyright and related rights legislation that applies to your use. For other uses you must obtain permission from the rights-holder(s) directly, unless additional rights are indicated by a Creative Commons license in the record and/ or on the work itself. This Thesis has been accepted for inclusion in WVU Graduate Theses, Dissertations, and Problem Reports collection by an authorized administrator of The Research Repository @ WVU. For more information, please contact researchrepository@mail.wvu.edu. 
A Good Persuasion:

Becoming Lysander in William Shakespeare's $A$ Midsummer Night's Dream

\author{
Landon Green \\ Thesis submitted \\ to the College of Creative Arts \\ at West Virginia University \\ in partial fulfillment of the requirements for the degree of \\ Master of Fine Arts in \\ Theatre \\ with an Emphasis in Acting \\ Jessica Morgan Bishop, MFA, Associate Professor, Chair \\ Dr. Jay Malarcher, PhD, Associate Professor \\ Jerry McGonigle, MFA, Professor
}

School of Theatre \& Dance

Morgantown, West Virginia

2015

Keywords: Actor, Process, Lysander, Shakespeare, Midsummer, Gladys G. Davis Theatre Copyright 2015 Landon Green 


\section{$\underline{\text { Abstract }}$ \\ A Good Persuasion \\ Becoming Lysander in William Shakespeare's A Midsummer Night's Dream \\ Landon Green}

"Lysander" is likely a title borrowed from the ancient Spartan admiral whose naval command was crucial to the resolution of the Peloponnesian War (Plutarch). His exploits as a Spartan navarch and steward against the forces of Athens, and then Thebes in the Corinthian War, were romanticized, as were many of the legends and history of Greece and Rome, by the time of William Shakespeare's writing of A Midsummer Night's Dream. Shakespeare must have felt it appropriate to set his fantasy romance in Athens, and to name the plot propellant lover after one of its most renowned conquerors. Lysander, for me, was a dream to perform and a much welcomed challenge. This thesis will center on my performance of the role at West Virginia University in the fall semester of 2014. I will track the process of embodying the role of Lysander; the love and hatred for the journey, and the satisfaction of coming to terms with "getting it right." To do this, I will analyze what preconceptions I brought to the production, what thoughts were altered or dropped, and what knowledge I gained through research and rehearsal aided by in-depth study of the text, themes, and plot specifically from the viewpoint of the character. 


\section{Table of Contents}

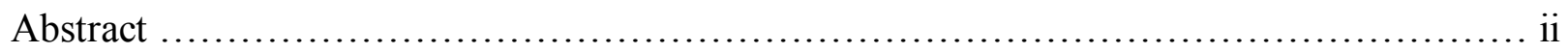

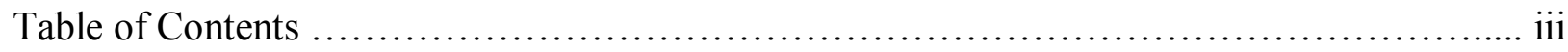

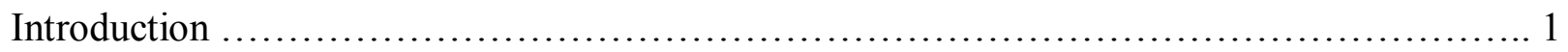

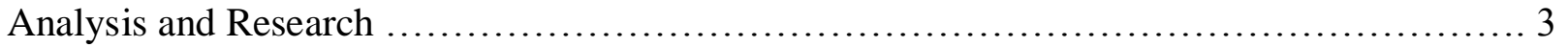

Act I, scene 1 ............................................................. 5

Act II, scene 2 ............................................................ 10

Act III, scene 2 ........................................................ 14

Act IV, scene 1 ........................................................ 19

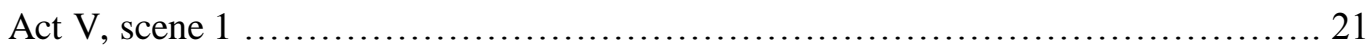

Terms, Phrases, Definitions .................................................. 22

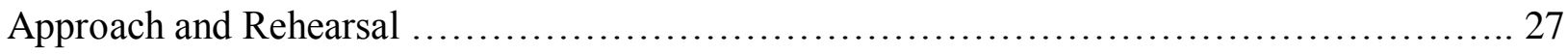

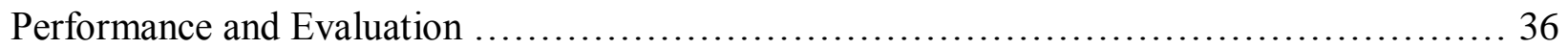

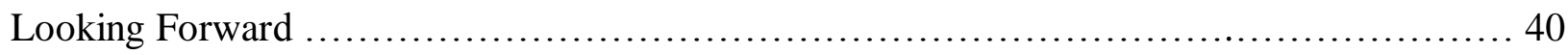

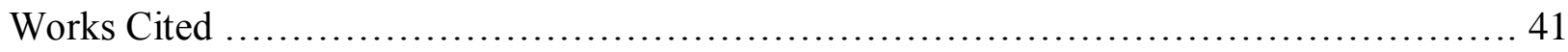




\section{Green 1}

\section{Introduction}

I sat eagerly in my middle school English literature class, awaiting my chance to play my part in our reading of William Shakespeare's A Midsummer Night's Dream. I was asked to read for Lysander in Act 3 - Scene 2, the "Lover's Quarrel," arguably one of the longest, most physical, and actively intense scenes in Shakespeare's entire canon. And, indeed, I had found it was. Our teacher had asked us to stand, mentioning this scene had to be put on its feet. She said that it would come to life out of the words, away from our desks. Excitement filled me as a handful of my good friends from the time read as Oberon, Puck, Demetrius, and Hermia. It neared my time. When it came, I bit at it with all the youthful vigor and unrestrained emotionalism as a pre-teenaged adolescent can muster. My best friend at the time played Demetrius, while two of the prettiest girls in school stood beside me. As Puck left the scene, I found it had gone by so fast, and that the room was filled with laughter and applause as we lovers "awoke" sprawled out in random spots on the portable room floor. Glory.

The teacher would later mention that I would make a fantastic Lysander in production. However, I had wanted terribly to read Puck in that far-off memory. Oddly though, when I found that I would be auditioning for "Midsummer" for a possible thesis role nearly 20 years on, I was torn. As a professional, I found that I played a "Puck"-like character in nearly all of the productions with which I had been involved: excitable, mischievous, playful, naïve. I wanted anything but to be left without a significant challenge as an actor for my thesis role. I have the rest of my life to revisit the desire to play the ageless Puck, and decided I would put attention on another character: Nick Bottom, the boorish knave. I had not even considered Lysander as much of an option. There were finer looking, younger, and better yet, others in the department who were actually living in the maelstrom of hormones that Lysander and the other lovers reside 
in. Although my spritely, impish nature and perpetually teenaged appearance leant more accurately to Puck, I tailored my audition to the role of Nick Bottom. However, I still found myself reading for Puck and, with slight surprise, Lysander. As the process went on, Puck fell away (with a subtle lump in my throat) and I found myself only reading for the role of Lysander, over and over. I would discover, at the age of 30 , I was going to play an ingénue. 


\section{Textual Analysis and Research}

In this section, I will go into detail about what Lysander says, what is directly said to him or about him, any character analysis to be inferred from dialogue, and research into any other facets of the text and references in relation to the plot of the action. What follows is my interpretation of the scenes and characters in which Lysander is involved through the filter of my research, preconceptions, and early tablework. Initially, during the tableworking phase of the rehearsal process, I went through the text and marked all the words that I was unsure of due to complete unfamiliarity or to unfamiliar context. I also included looking into a supposed inspiration for Shakespeare's characters. Shakespeare was deep into his own analysis of a collection of biographies known as Lives by Plutarch at the time of writing A Midsummer Night's Dream. He had taken much inspiration in his writings of Julius Caesar and Henry V from the men present within this compilation (Shapiro 133). The names of Lysander and Demetrius were both borrowed from the ancient Grecian naval commanders found here. These particular people embodied the ideals that made men legends, heroes ... men, points that Shakespeare used to caricaturize the idea of masculinity in his comedies. He accentuated the bravado and machismo, the lengths to which men would go to get what they want and "how" they want, and their quickdraw call to action. I found Lysander, as well as the other men within the script, to be cut of the same cloth.

The term "Midsummer" also refers to the longest day of the year, the Summer Solstice, which would also make for the shortest night in Midsummer's Eve. As a holiday, in Europe this refers to ancient pagan rituals of fertility and harvest (“Midsummer's Eve" WEB). For most of modern Europe, the holiday evolved as an observance of St. John the Baptist and garnered more religious connotations, but the idea that the holiday refers to new birth and bounty pervades. In 
Greece, since ancient times, the day is known as Klidonas, and, like other countries' observances, retained the idea that unmarried women would find their future husbands on this day. "They place a personal belonging in a pot and leave that under a fig tree overnight. The magic of the day is supposed to give the object prophetic powers" leading the women to prospective suitors (Taylor WEB). Fire, sexuality/fertility, and feasts reflect the cycle of birth, life, and death. Within the context of the play, these themes are deeply engrained within the story: a group of lovers find themselves surrounded by magic which leads them to their destined future. Further references in the script are made in regards to religious allusions, gods and spirits, and holidays, and will be expanded upon below. Also, all text is quoted from the Pelican Shakespeare Edition of A Midsummer Night's Dream edited by Russ McDonald (2000).

William Shakespeare wrote the play circa 1595 marking the beginning of his artistic maturity and his developing talent for multi-perspective and dimensional narrative (McDonald xxxi). The motifs present in the play focus on the love and sensuality through logic and instinct, the domestic and feral. The role of the magical realm plays significantly within the narrative as the catalyst for much of the conflict and action, as Fairy King Oberon and his attendant Puck do their best to influence the lives of those around them. There are also side-plots of the mechanicals putting on a performance for the Duke, Theseus, as a bit of comic relief, and the fairies tangible interaction with the mortal world. In outlining the synopsis, I will, however, focus mainly on the plot narrative as it pertains to Lysander's perspective. For example, though the audience is privy to the information that Puck mistakenly drugs Lysander instead of Demetrius, Lysander only has his own senses and faculties to judge his affections; and the Mechanical action remains a separate plotline for the entirety of the story until the final act. 


\section{Act I, scene 1}

The action kicks off with the arrival of Egeus and his party to the royal court. Lysander has been found serenading Egeus' daughter, Hermia. Egeus could not take this romancing of his daughter any longer and has taken it to the highest court. He has brought Lysander, his daughter, and Demetrius, to whom Hermia is previously promised, to testify before the Duke, Theseus (who, has himself, dealt with romantic issues). Egeus trades testimony and accusation against Lysander as Hermia defends his honor and the love they share, while Demetrius scorns him in pride. When all has been discussed, Theseus calls for a recess until his and Hippolyta's wedding day. This decision is met with distress and fanfare from all parties, save Lysander, as he and Hermia are inexplicably left to themselves in the courtyard. Lysander is ready to take these days to enjoy the remaining time with Hermia and work his magic with her father and the Duke. However, she convinces him that all is for naught, fighting a war for their love will not end happily. Lysander takes this as an all-or-nothing challenge and asks Hermia to run away from Athens, her father, and this society. In the woods, they will find his estranged aunt's home and marry each other under brambles and stars, not the law of Athens. Hermia leaps into his arms; retreat is their only hope at being together. When the decision is made, Helena wanders though and confesses the romantic complications she has with Demetrius. During the course of Hermia's consolation, she divulges their plans to escape, by which Lysander is slightly caught off-guard. He takes it in stride and reveals the plan in further detail, taking their leave as he does.

Now, in the first few lines of Lysander's entrance in this scene, I discovered who this character is: his past, social environment, traits, attitudes, and state of mind. The romantic, 
tempestuous Lysander grew into a young master from a wealthy merchant or artisan class family while his foil, Demetrius, came from wealthy nobility. Lysander works for his worldly wealth in opposition to Demetrius' inheritance of wealth and power. And so, he works for his affections. His initial scene with the court describes this as Egeus characterizes him and the relationship he possesses with Hermia:

$$
\text { Ege. }
$$

Stand forth, Lysander. And, my gracious Duke,

This hath bewitched the bosom of my child.

Thou, thou, Lysander, thou hast given her rhymes

And interchanged love tokens with my child;

Thou hast by moonlight her window sung

With feigning voice verses of feigning love,

And stol'n the impression of her fantasy

With bracelet of thy hair, rings, gauds, conceits,

Knacks, trifles, nosegays, sweetmeats - messengers

Of strong prevailment in unhardened youth.

With cunning hast thou filched my daughter's heart,

Turned her obedience (which is due to me)

To stubborn harshness.

Knowing this background helped illuminate my understanding of how Lysander interacts with those around him of varying statuses. Though Egeus does his best here to portray Lysander in a negative light, perhaps even using dark arts to charm the heart of his daughter, the romantic would infer that Lysander showered her with love and did his best to prove the lengths of his desire despite the wishes of her father. What seemed like smoke and mirrors to Egeus, was really youthfulness and perseverance that earned Lysander the worthiness as Hermia's object of affection. Egeus claims that Lysander had stolen, as a thief, Hermia's heart and faculties away from him, as if it were a personal attack. Hermia responds in defense of Lysander to both the 
Duke and her father with a fire that seems instilled within her due to love they share. This moment furthers the strength of the bond these two lovers share, concretizing the idea that Lysander craves this passion that burns within her or that is kept alit by him. She wishes that her father would see the same worthiness within Lysander as he does in Demetrius. Later, in response to Lysander's first words against the allegations, Demetrius declares that he stick to his place. Accusations and attacks come out of his bravado and aloofness in the form of this first "joke" in the play:

\section{Dem.}

Relent, sweet Hermia, and, Lysander, yield

Thy crazèd title to my certain right.

Lys.

You have her father's love, Demetrius,

Let me have Hermia's: do you marry him.

\section{I.1.91-94}

This phrase elicits the same connotations in the modern vernacular, and allowing me to easily intend the same meaning, as, "If you love her father so much, why don't you marry him?" In contrition to his quippiness, Lysander offers the king his character and romantic defense in contrast to what he perceives of Demetrius:

\section{Lys.}

I am, my lord, as well derived as he,

As well possessed; my love is more than his;

My fortunes every way as fairly ranked

(If not with vantage) as Demetrius';

And (which is more than all these boasts can be)

I am beloved of beauteous Hermia.

Why should not I then prosecute my right?

Demetrius - I'll avouch it to his head -

Made love to Nedar's daughter, Helena,

And won her soul, and she (sweet lady) dotes, 
Devoutly dotes, dotes in idolatry,

Upon this spotted and inconstant man.

There is a diplomatic air about Lysander. Not only does he impassion great arguments and poetry, but he aims for swift conclusions under evidence and examination. He outlines his social equality, or supremacy, with Demetrius here. He comes from an equally notable family, he possesses just as much material wealth though more of the intangible, and that the prospects of his pursuits match (and possibly overtake) Demetrius's own. However, being in receipt of Hermia's love truly separates the two in terms of earthly wealth. Besides that, Lysander is quick to point out that Demetrius already holds another's heart, that of Helena, daughter of another nobleman named Nedar, who is never mentioned again nor seen. Lysander argues here that Demetrius had romanced her in the same fashion as Lysander had Hermia, but he pairs that affection presently with inconstancy and rebuff, traits that they do not share. This argument, as well as Hermia's defense, has awarded the innamorati a stay of execution and a four day ultimatum. The proceedings, however, have left the lovers in the lurch after the court takes its leave. Lysander takes action in this scene. His course guides him to steady Hermia's conviction, not only for her sake but for his own.

$$
\text { Lys. }
$$

A good persuasion. Therefore hear me, Hermia.

I have a widow aunt, a dowager,

Of great revenue, and she hath no child.

From Athens is her house remote seven leagues,

And she respects me as her only son.

There, gentle Hermia, may I marry thee,

And to that place the sharp Athenian law

Cannot pursue us. If thou lovest me then,

Steal forth thy father's house tomorrow night, 
And in the wood, a league without the town,

(Where I did meet thee once with Helena

To do observance to a morn of May),

There will I stay for thee.

\section{I.1.156-168}

As it would happen, he sees in Hermia's complexion that she is unsettled. They banter back and forth over the frailty and difficulty in following love in their society as Lysander's consolation leads him to fully commit himself to their shared love. Lysander, with the entirety of his young heart and the full force of his audacity, makes the bold and sudden decision to wed Hermia. This was not some decision made lightly, nor had it spent a great length of time within the confines of Lysander's cranium. They will escape the law, which deems the Duke and Egeus with power over Hermia's life and be married in secret. Now, this passion and impulsivity are what I clang to in this analysis of Lysander's character. It also became my biggest challenge to match his energy and level of control, which I will later expand upon in further detail. Lysander also refers to a "morn of May," which may be in reference to May Day, another holiday much along the themes of fertility and harvest as Midsummer's Eve with more Anglo-Saxon origins ("May Day" WEB). Then, a gleeful surprise fills him when Hermia anxiously accepts his hand in marriage; and when Helena wanders on scene, Lysander exemplifies his openness to the friendship between the two women and divulges the outline of their escape from Athens.

$$
\text { Lys. }
$$

Helen, to you our minds we will unfold.

Tomorrow night, when Phoebe doth behold

Her silver visage in the wat'ry glass,

Decking with liquid pearl the bladed grass

(A time that lovers' flights doth still conceal),

Through Athens' gates have we devised to steal. 
The man is as cordial as he is diplomatic and impetuous. The two will commence their escape as soon as the moon, personified here as Phoebe, a titan born of earth and sky or Diana in Roman mythology ("Phoebe" WEB), rises and dew forms on the ground. When all is said and done, Hermia and Lysander part reluctantly. The next time they may express their words and feelings to each other will be the next day when they make the escape.

\section{Act II, scene 2}

The next Lysander is seen is after entering the forest with Hermia. They have spent hours making their way to his aunt's residence. Lysander guides Hermia through the darkened and shadowy terrain, as he attempts to gain his bearings. However, they have turned down the wrong path, and Lysander suggests that they rest for the evening together. She then swiftly ripostes his advances, and Lysander is found, sweetly, conceding his territory and pitching camp a short distance away. He sleeps. Before long, he wakes to the visage of Helena, who he finds surprisingly magnificent in her angelic glory. The audience knows this to be the work of a mistaken fairy named Puck, who erroneously applied a potion to the eyes of Lysander in place of Demetrius in order to have desire fall upon Helena. Lysander asks her where her former love, Demetrius, lies that he may do away with him. In an attempts to protect Demetrius, Helena pleads that Lysander go to Hermia. Lysander confides that Hermia no longer resides within his heart and that, powerfully, Helena has taken her place in his soul. To this poetry, Helena rebukes and rails, and Lysander finds that he is on the flat of his back with wounded cheek and wounded heart. She storms off, leaving him in both surprise and awe of her fire. Noticing Hermia's presence, still in repose through the dispute, Lysander concludes that he should end this arrangement while she rests, quickly and painlessly. Now, freeing his heart of Hermia's bonds, he shoots off to hunt his newfound love with renewed vigor. 
As the action opened upon Lysander and Hermia, they have already made their way through the woods and gotten themselves lost. It has been a long, weary trek. Hermia stumbles along:

$$
\text { Lys. }
$$

Fair love, you faint with wand'ring in the wood;

And to speak troth, I have forgot our way.

We'll rest us, Hermia, if you think it good,

And tarry for the comfort of the day.

$$
\text { II. } 2.35-38
$$

At this struggle and loss of bearings, Lysander suggests they lie together in no immodesty. Hermia mistakes this advancement as a pass at her before their marriage, and Lysander relents out of honor of their promise to each other, taking rest elsewhere. He is pure and honest (though maybe youthfully naïve) to Hermia and cordially (though very reluctantly) respects her boundaries. This scene exemplifies the situationally comedic circumstances under which they live. A bedside chat that leads to one party (the woman) rejecting the other (the man) in the sweetest way possible. This, however, was the one scene which I had interpreted differently from the director. In our final interpretation, Lysander clearly wants to bed Hermia now that they are alone, and "practically" married. The scene had become a tinge more blue-collar comedy, but the support is within the text. Now that the scene had been interpreted fully, this was another moment in rehearsal which I had a difficult time matching the energy and power that Lysander exhibits and holds over others. Once he sleeps, Puck enters and mistakes the pair for another duo of lovers. Puck, instructed by Oberon, was to apply a tonic from a flower to Demetrius' eyes to shift his affections toward Helena. However, applying the drug to Lysander's eyes, Puck leaves the scene as Helena trails Demetrius and stumbles upon Lysander who wakes to the vision of a newfound love: 
Lys.

And run through fire I will for thy sweet sake.

Transparent Helena, nature shows art,

That through thy bosom makes me see thy heart.

Where is Demetrius? O, how fit a word

Is that vile name name to perish on my sword!

Hel.

Do not say so, Lysander, say not so.

What though he love your Hermia? Lord! What though?

Yet Hermia still loves you. Then be content.

Lys.

Content with Hermia? No! I do repent

The tedious minutes I with her have spent.

Not Hermia, but Helena I love.

Who will not change a raven for a dove?

The will of man is by his reason swayed,

And reason says you are the worthier maid.

Things growing are not ripe until their season:

So I, being young, till now ripe not to reason.

And touching now the point of human skill,

Reason becomes the marshal to my will

And leads me to your eyes, where I o'erlook

Love's stories, written in Love's richest book.

II.2.103-122

Lysander has slept peacefully, almost in death-like repose according to Helena's description. As Helena stirs him, it is apparent that the effects of the potion have taken hold immediately. As the director had said, a fire has been lit within Lysander, and so I, too, had to allow that fire to transfer from Hermia to Helena. We spent many nights getting this monologue to flow out of me like flame from a pit, that the energy is both controlled, yet not. Words and poetry once reserved for Hermia have shifted their aim toward Helena, and his disgust for Demetrius has increased sevenfold. Helena thinks he is joking or confused. It takes half of a thought for Lysander to 
confirm the truth that now stands before him, and he deftly proofs his answer; in the process, illustrating his artistry at problem solving and romancing in the same action. In rebuff, Helena shoots accusation at his motives and character. All of these attacks do not mesh with Lysander's equation. At the moment Helena exits, he understands the problem lies in Hermia's presence, and chooses to cut all ties:

$$
\text { Lys. }
$$

She sees not Hermia. Hermia, sleep thou there,

And never mayst thou come Lysander near.

For, as a surfeit of the sweetest things

The deepest loathing of the stomach brings,

Or as the heresies that men do leave

Are hated most by those they did deceive,

So thou, my surfeit and my heresy,

Of all be hated, but most of me!

And, all my powers, address your love and might

To honor Helen and to be her knight.

$$
\text { II.2.135-144 }
$$

Now, I could never relate directly to breaking a relationship off with anyone as harshly, but I do have the magic "what-if." This is a fantasy that Lysander gets to play out, as he clearly knows she is asleep, but will hold parties witness for his account whether conscious or not. The potion has caused an opposite reaction for all those he has loved before, turning it to hate in order to facilitate the immense appetite of desire for Helena. He despises Hermia, and the power of the drug seems to hijack Lysander's ability to quickly make decisions. Again, the challenge was posed as to how I, in performance, would match his thought process and tempo. Lysander leaves with all his energy and vigor focused squarely on his pursuit of love, abandoning Hermia in the forest as he flies. 


\section{Act III, scene 2}

At this point, Lysander has been pursuing Helena through the wood outside Athens, confessing and professing his undying affections towards her. At every turn, she bats Lysander down, pushes him away, prompting him to push back even harder. This is, until she claims that he does all this professing in order to scorn her. This cracks him down to the core of his being to the brink of tears. He pleads, that his love is true and without motive, and just as he thinks they are making a breakthrough, Demetrius appears and professes his undying desire for Helena's heart. Again, this is due to Puck's attempt at a correction of his previous error, as Oberon bore witness to Hermia and Demetrius quarreling in the woods over shifting desires. This confuses both Helena and Lysander, and puts it in her mind that the men, together, devised this scheme to make a joke of her. Lysander believes Demetrius is the one who is feigning desire for a laugh, pushing them to make a deal: that Lysander give him Hermia's love in exchange for Helena, no strings attached. As Demetrius denies Lysander this transaction, Hermia stampedes onto the scene and into Lysander's arms. She catches him off-guard as she showers Lysander with both affection and scorn due to their separation. At this, he reiterates his stance on their relationship as he had initially stated while she slept; telling her that he not only fell out of love with her, but hates her with all of his bile, and that all of his attention and admiration now falls solely on Helena. She doesn't seem to understand the situation and confronts Helena. Lysander stands his ground believing Helena will easily handle the situation. She illustrates to Hermia their sisterly relationship and how this petty situation threatens to set it to ruin. The argument of rights escalates as Lysander then challenges Demetrius's love, Hermia pleads for Lysander's, and he, in turn, scorns her yet again for her naiveté. Like lightning, Hermia lashes out at Helena and it has become Lysander's job to protect his love from harm; however, he dare not touch Hermia, for he 
fears she may latch on and never lose her grip. But, like putting a dog past its use to pasture, he must ultimately settle the relationship with Hermia. He throws her to the ground, spitting insults at her. He breaks her spirit and tells her "no more." Demetrius taunts him a final time, and they take their fight deeper into the wood, leaving the women to their own devices.

From the moment Lysander enters at the top of this scene, he has exhausted his ability to woo Helena, and now only tears remain. The energy that awoke within when he himself woke has been drained from his body, while it seems Helena's ability to rebuke and trek on remains ever vigilant:

$$
\text { Lys. }
$$

Why should you think that I should woo in scorn?

Scorn and derision never came in tears.

Look, when I vow, I weep; and vows so born,

In their nativity all truth appears.

How can these things in me seem scorn to you,

Bearing the badge of faith to prove them true?

$\mathrm{Hel}$.

You do advance your cunning more and more.

When truth kills truth, O devilish-holy fray!

These vows are Hermia's. Will you give her o'er?

Weigh oath with oath, and you will nothing weigh.

Your vows to her and me, put in two scales,

Will even weigh; and both as light as tales.

III.2.122-133

This is where I learned of the limit of Lysander's ability. Debilitating frustration enters and compromises his ability to formulate cogent arguments. She has verbally attacked him, denouncing his honor and love. Yet, though she has left him brokenhearted and spiritless, his stubborn intellect carries on the work of proving love where exhaustion and frustration have taken their toll. He is a man with no options, but the goal he has set before him. Even as he 
fails, Lysander continues with poetry as his entrance is met with a sonnet proclaiming that even this depression is meant as devotion. Helena responds in kind with her own poetry in seeming mockery: even if true, what value does Lysander's devotion hold when he is previously devoted to another? She states that his words have no value, to which Lysander hastily responds: "I had no judgment when to her I swore." This is akin to admitting he made a dumb decision. Helena agrees that his haste in pursuit of herself is quite the same idiocy. When Demetrius awakes, he now professes his affection to Helena, where once he ran. Lysander's problem solving skills and nonchalance come out again when he makes a bargain with Demetrius over possession of marriage rights.

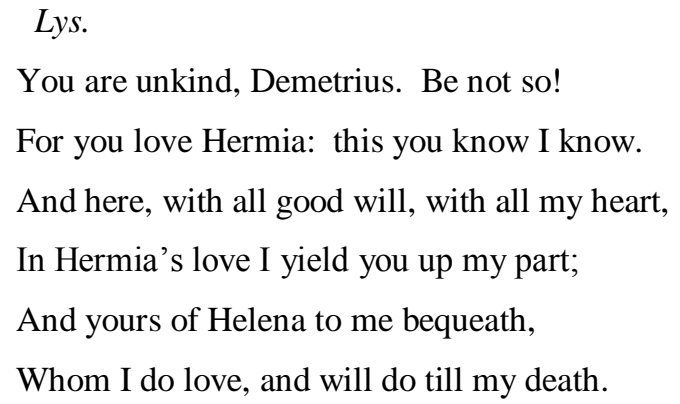

III.2.162-167

Demetrius swiftly denies the proposal, and Lysander must protect his pride. However, before he can interject, Hermia storms the site and attacks Lysander with affection:

\author{
Her. \\ Dark night, that from the eye his function takes, \\ The ear more quick of apprehension makes. \\ Wherein it doth impair the seeing sense, \\ It pays the hearing double recompense. \\ Thou art not by mine eye, Lysander, found; \\ Mine ear, I thank it, brought me to thy sound.
}


But why unkindly didst thou leave me so?

All of the boisterous dealings have led Hermia back to Lysander through the dark woods. The three quarrelers, most especially Lysander, had given Hermia the trail of screams and cries that caused this reunion. She could not see her way through the forest, but she could hear exceptionally the voice of her lost love. Now, with all of Lysander's remaining kindness and chivalry toward Hermia, he desperately tries to let her down softly while informing her of the disgust he holds towards her, reiterating the same emotion as he did when she was at his feet asleep. This fails miserably and spurs Hermia on to confront everyone in the scene, aggravating her passion for Lysander. Helena grows weary of this ado and attempts to make her exit, but before she can

Her. Sweet, do not scorn her so.

Dem.

If she cannot entreat, I can compel.

Lys.

Thou canst compel no more than she entreat.

Thy threats have no more strength than her weak prayers.

Helen, I love thee; by my life, I do!

I swear by that which I will lose for thee

To prove him false that says I love thee not.

Dem.

I say I thee more than he can do.

Lys.

If thou say so, withdraw and prove it too.

Dem.

Quick, come! 
Lysander's passion, again, takes over. Nothing stands in his path to Helena's heart: neither Demetrius, Hermia, nor Helena herself. This is the first moment where Lysander flexes his muscles in order to intimidate Demetrius. He throws threats at all and regards all as opponents. His machismo is exposed. Then when Hermia chastises, yet pleads with, Lysander, his temper explodes. His intelligence and suavity could not relinquish the bond he had with Hermia, and he must now break it. What follows is a tirade where Lysander degrades Hermia based on her complexion and over-persistence. He hands out slurs yet will not harm her physically as a way to rid himself of her presence. Demetrius notes this as feign attempts for Lysander to loose himself from her bond, calling him out on it:

Lys.

What, should I hurt her, strike her, kill her dead?

Although I hate her, I'll not harm her so.

Her.

What, can you do me greater harm than hate?

Hate me? Wherefore? O me, what news, my love?

Am not I Hermia? Are you not Lysander?

I am as fair as I was erewhile.

Since night you loved me, yet since night you left me.

Why then you left me - O, the gods forbid! -

In earnest, shall I say?

Lys. $\quad$ Ay, by my life!

And never did desire to see thee more.

Therefore be out of hope, of question, of doubt;

Be certain. Nothing truer. 'Tis no jest

That I do hate thee and love Helena.

III.2.269-281

Lysander tears into the two with fervor. He has run out of alternative arguments, and relies on pure rage. In light of the circumstances, they have all become monsters of rage and grief. When they have exhausted their reserves of put-downs and slanders, Lysander solidifies his stance with 
Hermia and his confrontation with Demetrius. Lysander resorts to using the words and observations that have hurt Hermia most: those pertaining to her height. With adrenaline and testosterone at their full tilt, Demetrius reignites the battle of masculinity, and they set off "cheek by jowl." As they take chase, they are met with winding paths and Puck's spirit in the guise of each other's voice. Clearly, the men are both willing to duel it out as Puck exacerbates the energy. Lysander, fatigued from near misses and endless running, prompts one final declaration as he lays himself down in sweat and lost breath:

Lys.

He goes before me and still dares me on;

When I come where he calls, then he is gone.

The villain is much lighter-heeled than I.

I followed fast, but faster he did fly,

That fallen am I in dark uneven way,

And here will rest me. Come, thou gentle day.

For if but once thou show me thy gray light,

I'll find Demetrius and revenge this spite.

III. $2.412-420$

In his final moments, nothing but bravado remains. He still aims that he will wake and kill Demetrius. As he sleeps under the branches, Puck alleviates Lysander's condition. Oberon returns and enchants the lovers with the memories of the evening as if they were within a dream. When next he wakes, Lysander's faculties have shifted to their normal settings; rage subsided and all desire returned to Hermia.

\section{Act IV, scene 1}

As all of the lovers find themselves drained and sleeping as unknowing bedmates, Puck has caught up on his troubleshooting and applies a reversal on Lysander's attractions. Oberon does 
the same to Titania and Bottom, enchanting them with the events that have passed to be as a dream. As the fairies take their leave, the sound of the Duke's hunting horn wakes the lovers. Lysander and the others wake to the vision of previous adversaries: Theseus, Hippolyta and Egeus. The hunting party has born witness to adversaries and delinquents sharing bed far from the city. The Duke awakes them with a horn and, immediately, Lysander's analytical prowess shifts into gear:

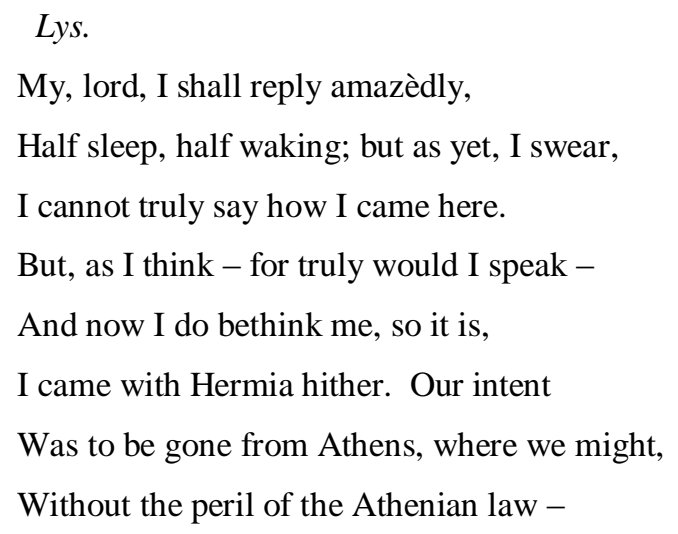

Although most of the evidence is absent as to construct a cogent argument, Lysander uses the absence of his memory to his advantage. Every possible thought, escape, or excuse speeds through Lysander's mind, nearly faster than he can keep up in his groggy state, until Lysander bravely and honorably admits to his transgression. This was to no avail, however, as Egeus quickly shuts him down, calling for capital punishment. But, to the amazement of the lovers: Demetrius speaks up about his falling out with Hermia, and falling in with Helena. A beautiful sentiment, were it not for the threat of punishment on Lysander's head for going above the law. Upon the king's exit, the four lovers voice their disbelief and perplexity towards the current situation and what may or may not have happened the night prior. Lysander points out in uncharacteristic bluntness that, regardless of the circumstances, they were all invited to hold 
marriage ceremonies with the king, and Demetrius settles that they should simply follow and recount about their dream-like occurences.

\section{Act V, scene 1}

Throughout the evening, they recount their faraway memories of the night past even as they are wed, and carry their revelry into the reception where everyone is to be entertained with a play. The ceremony has ended and the court holds their reception afterward. Theseus greets the lovers enthusiastically:

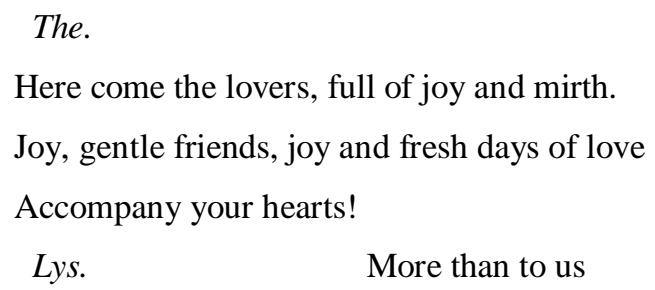

The group has obviously enjoyed themselves up to this point, regarding the joviality and familiarity they now share. Lysander even returns to his quippy jokes. While they celebrate, the king has lined up a show for the newlyweds to take in. A gang of laborers do more than satiate the court's appetite for buffoonery, gaiety and laughter with their rendition of "Pyramus and Thisbe." Throughout the festivities, the poor men on stage do their best as they are torn up by the heckling and criticizing of their audience. In the scene, Lysander has become a much more reserved character, not as quick as Demetrius and the King appear to be or have become. Perhaps he has become distracted by his newfound freedom to publicly display his affections to Hermia. Before the court knows it, the play has ended, and the toll chimes midnight as each couple is escorted to their respective wedding chambers to end the adventures in romantic fashion. 


\section{Terms, Phrases and Definitions}

Here I will transpose many of the terms in which I had been unsure of meaning or specificity of use in the order of scene and line number. They are then accompanied by their respective definition(s) found in the Webster's New Universal Unabridged Dictionary Second Edition (familiarly known to the cast and crew as "Mongo"). All terms in italics are paraphrased from the footnotes in the Pelican edition of the script.

\section{- $\quad$ Act I Scene 1}

bewitch $(27)-v$. 1. to use witchcraft or magic on 2. to charm; to fascinate; to please to such a degree as to take away the power of resistance bosom (27) $-\mathrm{n}$. 1. the breast regarded as the seat of the emotions 2. inclination; desire feigning (31) - adj. deceitful impression (32) - n. a vague notion or feeling fantasy (32) - v.t. to fancy; to admire nosegays (34) $-\mathrm{n}$. a bunch of flowers chosen for their fragrance sweetmeats (34) $-\mathrm{n}$. any sweet food or delicacy prepared with sugar or honey, as a cake, confection, preserve, etc.; specifically, a candy, candied fruit, etc.

prevailment (35) - n. prevalence; predominance; widespread existence filch (36) - v. to steal; pilfer crazèd (92) - adj. broken certain (92) - adj. sure; true; undoubted; unquestionable derive (99) - v.i. to originate possess (100) - v.i. to be owner of fortune (101) - n. good luck; success; prosperity vantage (102) - n. gain; profit; advantage; superiority boast (103) $-\mathrm{n}$. the occasion of pride, vanity, or laudable exultation prosecute $(105)-v$. to pursue with a view to reach, execute, or accomplish; to continue so as to obtain avouch (106) - v. to affirm openly; to cite as authority devoutly (109) - adv. with ardent devotion; piously; religiously 
dote $(109)-v$. to be excessively or foolishly fond

idolatry (109) - n. the worship of idols; excessive attachment or veneration for some

person

spotted (110) - adj. stained; blemished; sullied

inconstant (110) - adj. unsteady in affections or loyalties; fickle

chance (129) - v.i. to come or arrive without design or cause

belike (130) - adv. probably; likely; perhaps

want (130) $-\mathrm{n}$. something needed or desired but lacking; necessity

beteem (131) - v.t. to bring forth; to produce; to shed

tempest $(131)-\mathrm{n}$. any violent tumult or commotion

aught (132) - n. anything whatever

blood (135) - n. descent from nobility; royal or honorable lineage

enthrall (136) - v. to put or hold under strong influence; captivate

misgraff (137) - v.t. to obtain amiss

merit (139) - n. worth; value; excellence

momentany (143) - a. lasting a very short time

collied (145) - a. darkened; made black

spleen $(146)$ - n. 1. a fit of anger; 2. a sudden fancy; whim

confusion $(149)-\mathrm{n}$. defeat; ruin

crossed (150) - v.t. to be thwarted; opposed; countered

edict $(151)-\mathrm{n}$. an official public proclamation

trial (152) - n. an attempt; endeavor; effort

cross $(153)-n$. an affliction that tries one's patience or virtue

Fancy (155) - n. the monarch/god Love

persuasion $(156)-n$. that which induces

dowager (157) - n. an elderly woman of wealth and dignity

league (159) - n. a measure of distance; about 3 miles

sharp (162) - adj. severe; harsh; fierce; ardent; violent

Cupid's strongest bow, by his best arrow, with the golden head (160-170) - n. Cupid's

bow and arrow for true love

simplicity (171) - plainness; freedom of artificial ornaments 
Venus' doves (171) - n. those that clothed the goddess Venus and drew her carriage prosper (172) - v.t. to make fortunate or successful vow $(175)-\mathrm{n}$. a promise of love and fidelity promise (179) - n. expectation of successful prospect visage $(210)-n$. the face

- $\quad$ Act II Scene 2

troth $(36)-$ n. truth tarry (38) - v.i. to stay; to wait comfort (38) $-\mathrm{n}$. anything that makes life easy innocence (45) $-\mathrm{n}$. freedom from guile or cunning conference (46) $-\mathrm{n}$. the act of consulting together beshrew (54) - v.t. to curse Sleep $(64)-\mathrm{n}$. the embodiment of sleep transparent (104) - adj. 1. easily understood; 2. luminous, penetrating repent (111) - v.t. to remember with sorrow; to feel contrition tedious (112) - adj. wearisome; tiresome will $(115)-\mathrm{n}$. disposition or attitude toward others reason (116) $-\mathrm{n}$. the ability to think, form judgements, conclude keen (124) - adj. sharp, cutting, piercing mockery $(124)-\mathrm{n}$. that which deceives, disappoints, frustrates scorn $(125)-n$. expression of disdain; contemptuous treatment flout (129) - v.t. to mock or insult insufficiency (129) - n. inadequacy; incapacity perforce (150) - adv. of or through necessity surfeit $(156)-\mathrm{n}$. overindulgence; discomfort due to heresy $(158)-\mathrm{n}$. belief that is contrary to the fundamental doctrine

- $\quad$ Act III Scene 2 derision (123) - n. contempt manifested by laughter; ridicule; scorn nativity (125) $-\mathrm{n}$. birth badge (127) $-\mathrm{n}$. any distinctive sign or symbol faith (127) - n. credibility or truth 
devilish-holy fray (129) - a discord of truth and lies yield (165) - v.t. to pay; give in return; grant; permit bequeath (166) - n. to offer; to give; to hand down idle (168) - adj. 1. baseless; unfounded; 2. unfruitful; barren guestwise (171) - adv. in manner of a guest sojourn (171) - v.i. to dwell in a place as a temporary resident disparage (174) - v.t. to show disrespect for; to belittle lest (175) - conj. that; for fear that; or else aby $(165)$ - v.t. to pay for; atone for recompense $(180)-\mathrm{n}$. something given to make up for a loss press (184) - v.t. to urge on; drive on; compel bide (186) - v.i. to remain; continue engild (187) - v.t. to brighten yon (188) - pro. that or those at a distance o (188) - n. an object shaped like an O fiery oes and eyes of light (188) - stars bare (190) - v.t. to expose; reveal entreat (248) - v.t. to beseech; beg; implore compel (248) - v.t. to drive or urge with force; to constrain withdraw (255) - v.i. to go away; retreat Ethiope (257) - n. 1. loosely, a Negro; 2. a native of Ethiopia tame (259) - adj. harmless; ineffectual; impotent cat (260) - n. a woman who makes spiteful remarks burr (260) $-\mathrm{n}$. a person who clings tawny (263) - adj. brownish-yellow; tan Tartar (263) - n. 1. a person of an irritable, violent, intractable temper; 2. person of Mongolian or Turkish tribal descent medicine (264) - n. a drug or other substance, as a poison, potion potion (264) - n. a drink, esp. of poison or medicine erewhile (274) - adv. a short time ago earnest $(277)-n$. serious intention 
folly (315) - n. any foolish action or belief shrewd (323) - adj. evil; bad; wicked; mischievous vixen (324) - n. a shrewish, ill-tempered, or malicious woman minimus (329) $-\mathrm{n}$. a being of smallest size hinder (329) - v.t. to check in progression; to retard; to render slow hind'ring knotgrass (329) - low growing plant thought to stunt growth if ingested jowl (340) - n. the fleshy, hanging part under the lower jaw drawn (402) - adj. pulled out of the sheath plain (404) - adj. 1. smooth; level; flat; 2. open; clear

- $\quad$ Act IV Scene 1

concord (142) - n. friendly and peaceful relation enmity (146) - n. the attitude of enemies; hostility solemnity $(184)-\mathrm{n}$. 1 . festivity; 2 . a religious ceremony parted (188) - adj. divided; separated; split 


\section{Approach and Rehearsal}

My experience with performance has been to attack my roles fervently. I have always known myself to do this. I take to physicalization immediately, attempting to make specific and strong choices. I revel in the clumsiness of rehearsal; roughly sketching out the character and his place in the story from the multitude of attempted choices. Rehearsal is used to find truth and truthful points of view. As any actor should, I do the homework of knowing what my words mean, who I am talking to and why. It is extremely important that I analyze how the character speaks: Where are the stops and line breaks? What is the punctuation? When and why is it in prose or verse? But, being broad, being strong, being "wrong" are the ways in which I discover the true root of a performance as I dig my feet into any role. I do. This is something engrained in me from when I studied theatre at my undergraduate institution, the University of South Florida. There, I entered acting from a standpoint that I had to map out my character's life on stage. I was in my head too much, coming up with what was "right." Repeatedly, the phrase, "Get out of your head, and let it happen," sprung up in nearly all of my acting classes. I was trapped in my need to do something the right way, i.e., the character could only do "this" here and then "that" there. I spent four years discovering that if I let my own body and impulses live in the space with my scene partners. The noise would only need to be removed from the equation over the course of rehearsal. I have earned the trust of others in that my process will get me to the point of performance as long as there is an outside eye to help guide me by saying, “Try something else." I attached greatly to movement based courses, and physical theatre. The absence of voice equaled less thinking. I could become others physically, and that informed my thoughts and abilities as the character. When I am allowed the opportunity to explore physicality, in the space, with my scene partners I can discover the unwritten text of the 
character. That is simply something I do not know until I have found it, which is what I had not understood about why others would say to get out of my head. I thought I had the answer when I did not. When I have a made errant decisions and, along with the director, eliminated the weak and "wrong" choices can I ink the bold, strong choices that are used to fuel my performance and aid in the relationships we create on the stage. I throw a lot at the board, and something will stick, meshing with the director's conception, my abilities and truth. The other philosophy that I have stood by and had engrained in me has been to go big, because it is better and easier to pull an actor back than it is to push him up. It is not so much that I generalize my actions or character, as that I initially throw a lot of small specific choices at the rehearsal and systematically weed out weaker ones, strengthening the stronger ones. Soon, by full runs of scenes, these leftover choices would strengthen into supported truthful actions that can only be strengthened. It has always worked for me.

In my time within the Stanislavski-Meisner based training program as a graduate student at West Virginia University, the faculty took my ability to do and helped me refine it to be more specific. They also had hammered it into me that simply being and being simple could be just as bold and strong as larger, louder actions. I rooted this synthesis of being and doing within my process. So I brought this system of specifically doing and being simpler into the fold. I still felt the need to do something, just not as big.

However, looking back, I feel that this particular rehearsal process still fought incessantly against my own creative process. Though, what mattered during the process was how I could fit my own interpretation of characterization with that of the director. I tried my best to use his direction as a point of truth; I simply had to do it truthfully as much I would a piece of text or a stage direction from the script. He would say that we needed a handle on the use of the language 
before we allowed it into the body, while my personal process disagreed and that I needed to understand the physical life before the words. Still, I kept my confidence in the director's vision and ability to direct me, though that attitude may have sent me down the wrong path. In the moment, I would sincerely accept his attitude, that I was comfortable getting to know the words, but I would still want to use my body and my process. I fought myself to deny impulses for the sake of simplicity and language. For instance, I wrote in my actor's journal over the course of two evenings of rehearsal:

\section{October 16}

It's been great getting intimate with the words, and knowing them before fully memorizing. I get to memorize intent and get that into my bones along with the words. Our collaboration on mining the text has been fruitful, and I am ready to get down and dirty with the play and scene-mates. Anxious to truly enter the world and not worry about what I am saying.

(I am constantly fighting my urge to attack the words and the intention - and wondering why I do that and whether that's bad or not)

\section{October 20}

I am so lost. I wish I could just be told what [the director] wants; what he wants me to do and I just do it truthfully. I feel like it's a guessing game. I know what I am saying but not how to use it. I am getting frustrated with myself with all the [“I don't know"] and "wrong."

When I would bring my body into play, it was an endless barrage of "Don't do so much," and "Simplify." The director would give me actions, but more along the lines of how to act it rather than letting me discover an action naturally. Instead of concrete actable directions like "get her off of you" (whereby I had a failure or success of objective), it became qualitative or a non- 
direction in "struggle, but don't hurt her," at which I direct myself by asking, "how much? Is this enough? Am I hurting her?" Obviously, as both actor and character, I would not want to hurt the actress so the direction simply translated to what was written in the text: "to struggle." By the end of the rehearsal process, I felt I was beginning to grasp the character from a physically truthful point of view as my director interpreted it. This was a place where, in retrospect, I was far behind where I should have been. As he always pointed out, though, one of his favorite sayings derived from Constantin Stanislavski's work at the Moscow Art Theatre, "You go through months of rehearsal before you can even begin to slightly understand the play or character." Obviously, we only had a single month's worth of rehearsal, and we needed to know what we were doing in that relatively short time. In hindsight, I guess I should have had a real conversation with the director and told him to trust me and my process; that mine does not have to be his but that we will end up at the same place with less frustration on my part. And that is possibly the root of my frustration with the process, that I had forgotten to look at this process as academic, and entered it as a professional would ... bringing myself, my process and truths. I became too focused on getting the job done, and done my way, that I was left discouraged when I would be presented with a different way to approach a scene or action. I was impatient, and wanted to get my hands dirty quickly.

Now that being said, we took our time before getting on our feet, doing tablework for almost two weeks. I felt I did all of my homework - research of words, phrases and references for naught when we simply spent the evening of rehearsal redoing the research and discussing it. I wanted to start using it. However, when I did begin to start using the work, I was pinned into a "wrongness" of doing. I was challenged to enter a process of being. I believed all of my training in doing was working against me, and that my body and mind were being separated. My initial 
interactions with the characters were stunted. For example, many evenings where I, as Lysander, would move to Hermia or Helena during intimate scenes in order to connect through touch or proximity the meaningfulness of my love, I would be told that I was fussy or, "You like to touch/move toward people when you talk to them." Yes, true on all counts, but it felt too early in the process to execute harsh decisions like "don't touch the person you love." I understood that this was meant to have me form other paths of thinking, but it got to the point where I was directing myself. My "critical parent" voice took over in my head. I thought I was left trying to read my director's mind; and we spoke different languages. Later in rehearsals with the opening scene with Hermia, I would get upset with myself when I would not move toward her in consolation and show her she was loved, but yet I would be told to do something; "Look at all she is giving you! Do something with it!" I would do as the director said using my voice and the words, but in my head I would scream, "But she's not giving anything to me, she is over in her corner 'feeling,' while I am over here in my corner doing the same but with intention." I may have felt that we were all too busy "acting." This led to the overall sense that my process was being directed and not my actions. Again, this was meant to be pedagogical, but I had turned off my student brain when in application.

Once more, I should have spoken bluntly with the director about my feelings. I'm sure my miscommunication with him was what drove the frustration. I tore myself up over course we were taking. I felt helpless and not in control of my creative faculties. However, all quibbles I had with conflicting philosophies aside, the process is meant to be a learning experience. I took a lot from the work we did. I did my best to take the director's thoughts and words as an extension of the text. There were times which I didn't hang up on the thought process, and married this active analysis into my own process of doing. I attained a technique of active 
analysis that did not trap me in my head, but instead allowed me to interpret and produce these directions. But patience was probably what I took away most from the rehearsal. I should have been more patient, trusted that we would have gotten there. I was honestly scared that, although I had every confidence in my director, my confidence in myself to take that direction lacked. I must have felt that I was not going to be personally prepared when it came time to perform. When I gave up, or fought to give up, my process in order to facilitate the director's objectives I lost the trust in myself and put all of it into the vision and others. I feigned a confidence in myself, pushing forward thinking that "I may not have the answers, but there are others around me who have my back." Instead, I should have simply said, "I may not have the answers now, but they'll be there when I need them. Don't worry." To patience, I would have to add trust in myself that I know what I am doing, and that these directions are not falling into the vacuum of my ears. For instance, during rehearsal for the lover's quarrel (III.2.122-344), I had gained a mass of intention and meaning in my words, and was able to use it without trying, reflecting in my journal:

\section{October 31}

Today I got to just say the words. [The director] has started a shift into more concrete directions than qualitative ones for me. I've noticed a dramatic shift in my comprehension and execution of my actions. We went over the forest scene, over and over: proving my love to Helena, standing my ground against Demetrius, and letting Hermia have it - all directly and urgently (with fervor). Still it feels like I am missing some quality that [the director] wants. I feel strong communication when I am clear with my words and intentions rather than trying to show them.

But, as is explained here, I still felt an absence of some unknown quality that I lacked and could not fill in. And that sense of deficiency aided and exacerbated my overall frustration. 
But, between the text work and rehearsal, I got the idea of who Lysander is, who I am in his skin, and the relationships within the script and the world. Stillness was the defining characteristic of our (mine and the director's) Lysander. Lysander bides his time; he is cool and calculated. When the time comes, however, he knows how to attack with collected passion. There were few times where the action caught him off-guard, but when it did, he adapted quickly. Now, having said that, though I knew that stillness was Lysander's defining characteristic, as the actor I did not know how to use "non-action" in this sense of an action. Generally, the only way I, as a person or actor, have known to overpower another person's energy is through physicality, proximity, and volume. I overwhelm others energy by giving them an abundance of my own. The best active intention I could apply to Lysander was that he demands attention even in silence. He absorbs energy and spits it back out. The director and my textual interpretation led to this characterization: to be so exceptionally passive that it passes for aggressive action. I did my best to embody that vision, though I did not know how to apply active stillness to my physical life. My body-sense was dumbfounded.

My work with my scene partners varied somewhat. All of my fellow lovers were finishing up their final year in the program; two young ingénues as Hermia and Helena, and a physical actor much like me in Demetrius. Now, the work I did with the women was where I got most acting notes. I cannot say the reasoning behind that, but when I would interact with Demetrius (both being very body attuned actors) our ability to communicate with actions on stage flourished. He affected me; he would make me do something and would respond in kind. We could literally bounce off each other, and it would be truth. That is, perhaps, why I did not gel as much with Hermia and Helena. Agreed, they would make me feel towards them but I never truthfully felt the urge to do anything through their actions, to react. In retrospect, it 
seemed as if many emotions were being "acted" during our scenes together. We were separated due to the "no touching" rule, and it would be as if the women would be at one point on the stage being in their own world doing something and feeling, while I would have to affect them without moving. Unfortunately, I felt alone on stage. The personal truth I had brought was that if I wanted to touch someone I loved and thought loved me, I would. I got it in my head, with the director insisting the subtraction of physical choices, that I did not know how to touch someone directly with my words alone. For instance, when Helena wakes Lysander, all I wanted to do was hold her and caress the face that I was praising, especially since her face was centimeters from my own. However, that was halted because it seemed creepy. And it was. I would have had to agree if I were not in the moment. But if it were so creepy, why was the director the only one to notice it, why hadn't my scene partner? I was not given something to react to and change my tactic in the scene. Instead, I was given a non-direction to take away physical touch and find a different way of "bringing the fire" to every scene in which I intimately coerced my maidens. I was continually riding a single tactic on my lines, and it discouraged me as the actor, because all I can think is "do not touch" and from my truthful and personal point of view, the act of touching is substantially present. Eliminating the use of touch in turn eliminated a host of actions I knew how to use, but without helping me find the ones that I am sure would have been acceptable to our vision of the character. This comes back to the notion that I was directing myself, moving toward my denial of impulse rather than the free-flow of impulse which would lead to natural discovery of live-and-learn. I, of course, did not lose my confidence in my partners, and laid all the responsibility and inability on myself. At which point, I thought of myself as clunky, stiff, and uninspired on stage. 
However, as I would discover, all the difficulties I encountered and the state of imbalance left me prepared to sink my teeth into the role. All in all, our (mine, my partners', and director's) work all came together by the time we were in full runs and technical rehearsals. We were show ready, though some tweaks and character relationships were still to be refined. Once the hard part of getting through the rehearsals and getting the director what he needed was out of the way, I was ready to get to work, start getting notes and personalizing the performance. I should have placed more trust and patience in my own abilities to comprehend, even subconsciously, and execute as I did in my director and scenemates, knowing that this was the process of this particular rehearsal. 


\section{Performance and Evaluation}

After all that was said regarding the official rehearsal process, I must say when we were in the week of technical rehearsals, my ability to explore and live in the role expanded greatly. I made choices and took actions deeply rooted in the foundations we formed during the process of rehearsal, and finally realized that I was worried about the process for silly reasons. We got where we needed to be, when we needed to be there. For me, the work opened up at first dress rehearsal. Prior to that evening, we had not run our scenes in sequence nor had we integrated the various plots together. This night we ran scenes end to end, in our skin and clothing, in the atmosphere on the hills and branches around the tree. I unshackled myself from my "critical parent" internal voice, and granted myself the freedom to live on the stage without a focus on censorship and nary an interruption to the flow. Once we finished a run, we would get notes and run it again with the adjustments. Our director gave concrete ideas and notes, workable from perspectives of truth that I had developed from the life I had developed in rehearsal. I could feel others react in the same way. Their objectives clearly stood in front of mine, and we lived with different paths intersecting at the appropriate points. We were all alive and moving. The work we had done, frustration and all, paid off with our ability to live.

With the full runs, I never had to think about the question, "Is this something Lysander would do?" Thanks to rehearsals and the obstacles that I encountered therein, I had already become him; we established his history and his mind with me in the driver's seat. All I had to do was go. During opening night, I was fueled by our first audience. Their energy lit me up with my entrance and my first line. Most nights, my entrance would elicit giggles from the audience. I obviously looked a little silly with my swooped down, greaser punk hairstyle and leather jacket on this small frame of a man (our production's physical conception of his appearance). When 
my first jab at Demetrius departs my lips, the audience regularly broke out in chuckles. The first time this happened, I discovered something so obvious ... our version of a streetwise, punk Lysander is compensating and putting on a show. Lysander postures and expresses himself to cover up the sensitive romantic; much like our prudence strives to subdue our romance. I took this new knowledge, and lit the proverbial "fire" under my performance. This was what was needed to replace the absence of touch to keep me active, rather than for stillness and physical separation for its own sake. It was better late than never that I realized this.

With the audience fueling my fire, I felt a momentum of energy that always led me to the end. The opening scene where I defended myself against Egeus was backed by my need to protect my ideals and love, which also led into my swift proclamation of marriage to Hermia. This fire powered my need to be close to Hermia in the wood, but then save our bodily warmth for the prosperity of our wedding bed. All this energy then surged. Power shifted abruptly to aim at Helena after the potion is administered to my eye, and all of the reprisal Helena feeds me, further impassions my pursuit. This pursuit shakes the very bones of my character ... shifting wildly between grief and scorn and maddening desire. Further, Hermia's chase enrages my bile and spirit. My craving of Helena is so immense that it cannot afford any tendencies to others. All others are enemies to our passion. I backwardly threaten the urge to strike and break Hermia, and continue to charge Demetrius in combat, calling for his elimination. We collapse from exhaustion, and when we wake, the mental taxation has taken its toll. I have awoken completely incapable of coherently forming my thoughts. It spews out of my mouth without control or thought as to what I am saying and the consequences therein. When the dust settles, respite from the excitement entreats our desire as we make our way to a wedding night. After all of this has happened, I find myself, as Lysander, resting in Hermia's arms with most of my attention split 
between the stage show and her eyes. Lysander has no more words to speak, save the odd crack at the mechanical performance. This also becomes how I felt at the end of every showing. My emotional and mental faculties are drained; and all that calls me is the curtain, applause, and the drive home. I gear up to continue the sequence again the next day. I would not spend my nights any other way.

Overall, I believe my execution of the role went well. In my opinion, it was not the greatest performance of Lysander ever produced; I was still clunky, playing broad generalizations, and never once kissed Hermia until the final show, but I believe I handled it suitably. My job was done to the fullest extent of my abilities to expand my range from leading man's best friend into the role of leading man himself. I was reminded that though I was thirty years old, as an actor I am still a young man in an old man's game. We were, as a cast, reminded nightly that $A$ Midsummer Night's Dream was an ensemble performance: no one person carried the show on his or her back. I fit into the grand scheme of the plot as one gear would in a simple machine. Each actor was to do their job for the sake of the others in order to cohesively streamline the performance. In this I succeeded. The general consensus among audience meetand-greets was positive; they felt both a good and bad attitudes towards the character of Lysander and his actions, not only that they enjoyed my performance of it. Older women would come up to me and say something like: "I'm glad you turned out to be such a nice boy in the end." The younger women would simply stare and giggle, especially on nights where I heard catcalling whenever I walked on stage. And, the parents, like Egeus, would say to the effect, "Watch where you're putting those hands;" a nice callback to the "no touching" rule. Fellow cast members, and even the director, would come up post-performance and say something along the lines of, "What you do isn't easy, but you are making it happen. Good job!" And if success 
were measured on the level of enjoyment I had being Lysander among my scene partners in $A$ Midsummer Night's Dream for those few brief weeks, I would say I succeeded admirably. 


\section{Looking Forward}

As I left the production behind and began preparation for writing this thesis, I reflected on what I had taken away and what my training up to this point has left me with. I am a big actor in a little body. I compensate much of the time for my lack in size with my consumption of atmosphere and energy. Through my years of training, I have learned to let go. This experience holds examples of when I should have let go, what happens when I do not, and when I do. Years of working under the gun, so to speak, to get a production on its feet has left me impatient and taking shortcuts. This process has reminded me of the importance of holding trust and patience for myself without holding it in spite for others. It has allowed me moments to refocus what it means to work. The frustration was one layer that evidenced the work being done. Making sure I stay busy in rehearsal does not simply equate to accomplishing work, and I must allow myself patience and exert that energy into study. My state as an actor has gone from analytical mapper to physical firecracker to something in between. I take from this experience, both in production and in training, the tool to stay in the act of doing but to be simpler ... to stay strong, but simpler can be an option. I can be comfortable being, and that maybe there is not a right or wrong answer, and that I have to do and find out later. Meisner training has taught me that specificity does not just mean more detail, and that my attention must be fully on the task at hand, yet fully on my scene-partners, as well. Focus has improved greatly for me these past few years in the training program. Noise both in my body and mind has been filtered very finely. As an educator and director, I can now appropriately articulate my words in order to facilitate growth in those I am in charge of. "Simpler," "tactic," "purpose," and other terms are no longer foreign. I can ask a student or actor, "What are you doing?," and guide them to a strong, specific answer. I can now understand through my own frustrations that there are two schools of thought. There are 
those who gravitate to the words and those who gravitate to physicality (the inside-out and the outside-in, the Grotowski and the Stanislavski); something that I had known intellectually but did not really ruminate on. I feel I can better identify, approach, and facilitate those of both parties in production and the classroom because of my time in the program. Nevertheless, the most powerful gift that has been bestowed upon me as a theatre practitioner has been the power to say, "I don't know," and it not be a four-letter word. I have the tools to comprehend and create within me, the trust to use it, and the patience and assurance that those around me are able to help. The phrase has been empowered with a new constructive sense for the actor, educator, and all-around artist in me. To say, "I don't know," only leaves me to then state with confidence, "But we'll know when we get there." 


\section{Works Cited}

"May Day." Encyclopaedia Britannica. Encyclopaedia Britannica Online Academic Edition. Encyclopædia Britannica Inc., 2015. Web.

McDonald, Russ, ed. A Midsummer Night's Dream. The Pelican Shakespeare ed. New York City: Penguin Books, 2000. Print.

McKechnie, Jean L. ed. Webster's New Universal Unabridged Dictionary. Second ed. New York City: Simon \& Schuster, 1983. Print.

“Midsummer's Eve.” Encyclopaedia Britannica. Encyclopaedia Britannica Online Academic Edition. Encyclopædia Britannica Inc., 2015. Web.

"Phoebe." Encyclopaedia Britannica. Encyclopaedia Britannica Online Academic Edition. Encyclopædia Britannica Inc., 2015. Web.

Shapiro, James. A Year in the Life of William Shakespeare: 1599. First Harper Perennial ed. New York City: HarperCollins, 2006. Print.

Stewart, Aubrey \& George Long, trans. Plutarch's Lives. Vol II. London: Project Gutenberg, Aug. 22, 2012. Web.

Taylor, Victoria. "Summer solstice customs involve sex, fire and ... herring?" The Daily News. NYDailyNews.com, 21 Jun. 2013. Web. 